\title{
渝东南休闲农业发展对策研究
}

\author{
再敏芳 \\ 重庆市黔江区委党校 \\ DOI:10.32629/er.v1i3.1498
}

[摘 要] 近郊休闲农业是现代农业的一个重要部分, 它在增加农民收入、建设社会主义新农村方面有着其独特的作用,同时, 发展近郊休闲农业也是促进城乡居民消费升级、缩小城乡差距带动当地经济的一个重要举措。本文基于对重庆市休闲农业发 展状况的研究, 提出了重庆市发展休闲农业的对策。

[关键词] 休闲农业; 重庆; 发展对策

发展休闲农业一方面可以促进农村产业结构调整, 延长 农业产业链, 带动农民就业, 同时还可以促进农村剩余劳动 力快速转移, 促进农村土地流转, 为农业规模化生产提供有 利条件。另一方面休闲农业有利于城乡在科技、医疗、教育、 信息等方面进行沟通交流, 使城市人了解农村文化和农业生 产, 农村人转变发展观念和提升素质, 促进城乡协调发展, 从 而实现现代农业的健康、可持续发展。

\section{1 休闲农业相关概念介绍}

休闲农业源于休闲产业, 而休闲产业泛指提供休闲服务 及满足休闲需求的产业。目前, 国际上对休闲农业概念的界 定尚未统一, 国内外文献中常常出现如 “休闲农业”、“观光 农业”、“旅游农业”等多种说法, 国内学者一般认为休闲农 业与观光农业、旅游农业等同。根据国内学者对休闲农业概 念研究的不同侧重点, 现行的休闲农业概念分为三类：以 “农”为主的休闲农业、以 “旅” 为主的休闲农业以及复合 型产业的休闲农业。

\section{2 重庆市休闲农业发展条件}

2.1 重庆资源优势明显

重庆山地和丘陵面积达 $80 \%$ 以上, 森林覆盖总量 303. $42 \mathrm{~km} 2$, 山地农业资源丰富; 重庆江河众多, 构成了以河 谷流域的垂直景观、丘陵低洼部分的平坝农业景观等多种休 闲农业立体景观带; 重庆动植物资源丰富, 北碚缙云山、南 川金佛山、武隆仙女山等国家级森林公园环境优美, 夏季避 暑, 冬季滑雪等活动逐年增加。重庆民俗文化深厚又独特, 聚集了汉族、苗族、土家族、回族等少数民族, 各民族之间 形成了相对成熟的特色饮食文化、生活方式等。

\section{2 重庆交通条件优越}

重庆除了被称作 “山城”, 它还被称为 “水城”, 全市贯 穿嘉陵江和长江, 水路通达; 近年来重庆逐渐形成了以主城 为中心, 直接连接全市 $90 \%$ 以上的区县高速公路骨架, 农村道 路整修良好, 只要各区县有有价值的休闲农业项目活动, 打 造出旅游品牌, 人们都可以有机会坐车前往。

\section{3 重庆消费市场大}

重庆拥有近 3000 万人口, 人均 GDP 逐年增加, 繁重的工 作压力让越来越多的人产生了强烈的旅游动机, 休闲旅游农
业市场也逐渐扩大。重庆拥有 “山城” 之称, 许多游客都慕 名前来游玩, 浓厚的巴渝文化深深吸引着一批又一批游客。 另外, 重庆 “火锅” 和 “美女” 这两张名片也吸引了不少消 费者, 来重庆游玩吃地道正宗的重庆火锅也成为了不少游客 来重庆的动机之一。

\section{3 重庆休闲农业发展存在的问题}

3.1 科学规划不到位

我国大部分地区的休闲农业基本是以农民自主、乡企合 作进行开发, 缺少科学整体规划, 部分景点项目较为单一, 功 能不全, 档次不高, 布局不合理。同时这些观光休闲景区的基 础设施不完善, 市场定位不准, 没有科学的管理和法规制度, 不能很好地与市场接轨, 因此, 经营较为无序混乱。另外由于 规划不到位引起游客的安全, 卫生等得不到满足, 同时在项 目具体开发建设方面也存在一定的盲目性和混乱性, 导致休 闲农业发展受到阻碍。

\section{2 管理及服务水平较低}

重庆农业休闲现有制度和管理机制不健全, 农业及旅游 部门职能混乱不清, 工作分工不协调。大部分休闲农业旅游 区的道路、园林绿化、风险防控、管理服务以及食品安全没 有统一的标准和制度, 无法进行规范管理。因此, 游客的住 宿、餐饮、娱乐等卫生、安全问题得不到保障, 影响了休闲 农业的稳步发展。

\section{3 服务人员的素质不高}

重庆休闲农业从事管理和服务的人员基本都是本地从 事劳动生产及外出返乡人员, 这些服务人员拥有大专以上学 历的毕业生较少, 服务人员基本都是初中及以下学历, 教育 程度较低, 缺少旅游和农业等专业服务技能和相关专业知识, 不能满足游客的要求, 导致景区的服务水平和能力不高, 阻 碍休闲农业的快速发展。

\section{4 档次及品位偏低}

虽然近年重庆休闲农业正在健康发展, 但发展规模较小, 品牌不强, 功能单一, 多数 $\mathrm{x}$ 休闲农业区设施薄弱, 休闲产品 内容不丰富, 缺少生态、人文理念的灌输, 内涵及品位不高, 市场竞争力不强。真正具有高品位、多功能的休闲农业景区 不多, 基本都是常规化的旅游项目, 酒店规模和品位不高, 旅 
游产品没有创新性, 满足不了人们日益增长的旅游和休闲需 求。

\section{4 重庆休闲农业发展的策略}

4.1 科学规划, 突出体闲农业特色

发展休闲农业, 做好科学发展规划是关键。一是要遵循 科学发展理念, 注重发展的同时更要注重生态保护, 要将经 济效益和生态效益结合起来, 因地制宜, 合理布局景点, 突出 地区休闲农业的特色。二是要重点开发乡村文化资源, 突出 乡村地域特色, 增强旅游产品内涵。三是要详细调查当地资 源优势、市场容量、周边环境和区位条件等因素, 根据功能 制定发展方向和目标, 打造休闲农业品牌。四是要重视乡村 环境保护, 把资源开发和环境保护结合起来共同发展。

重庆黔江区委区政府提出的在 2019 年建成三塘盖 $4 \mathrm{~A}$ 级 景区, 三塘盖乡村旅游开发从乡村旅游到景区最终形成度假 休闲游的发展模式, 建成独具特色的高山休闲度假区, 实现 农业、文化、体育等与旅游融合发展, 成为乡村振兴示范点。 目前, 正在全力推进游客中心、停车场、旅游则所、云浪酒 店等硬件设施建设和白沙塘、长莲池民房改造, 以及游览系 统、安全系统、智慧系统等配套设施建设。整理三塘盖景区 文化内涵资料, 提炼特色文化主题, 辅以民俗文化元素, 丰富 景区内涵。通过软硬件设施的建设和完善, 确保 2019 年底建 成 $4 \mathrm{~A}$ 级景区。

\section{2 提高对发展休闲农业的认识}

只有充分重视休闲农业, 才能更好地推动休闲农业发 展。(1) 充分认识发展休闲农业的重要性。休闲农业对地区 经济增长, 增加农民收入, 促进农业结构调整具有重要意义。 (2) 重视农耕文化资源的开发、利用和保护。(3) 重视住宿、 餐饮、金融及运输等服务业的带动作用, 从而带动农民进行 就业。充分认识发展休闲农业对推动城乡一体化、改善农村 生态环境、提高农民文化素质及建设美丽乡村的重要性。黔 江区结合市民下乡休闲、娱乐的需求, 围绕 “春季观花、夏 季纳凉、秋季采果、冬季观雪” 的季节特点, 着力加快白土 三塘盖、小南海十三寨、金溪千年银杏及情人谷、水市水车 坪、石会中元、沙坝三台、五里乡五里社区、蓬东麻田村等 休闲农业示范点建设。区委区政府大力重视休闲农业, 以休 闲农业为契机, 带动地区经济增长, 增加农民收入。

\section{3 规范管理, 提高服务质量}

一方面, 要制定和出台休闲农业发展标准和法律法规, 要建立健全规章制度, 从休闲农业申报审批、人员上岗培训, 食品安全、卫生及医疗保障、价格制定、经营管理等多方面
给予支持。另一方面, 要加大对服务管理人员及服务人员的 培训力度, 增强他们的服务意识、服务水平和业务能力。此 外, 应建立淘汰奖励机制, 定期对休闲农业景点进行评估, 政 府要充分发挥监督管理作用。

4.4 加强景点基础设施建设, 拓宽投资渠道

休闲农业的发展应该采取多元化投资形式。一方面政府 要设立专项资金用于休闲农业的发展, 扶持的重点应以景点 交通、排水、供电、环境治理等基础设施建设为主。另一方 面要拓宽投资渠道, 鼓励和引导农村信用社等金融机构参与 休闲农业的发展, 并提供各方面信贷支持。此外, 要放宽政策 吸引外来企业进行投资建设, 提高建设标准。

\section{5 加大宣传和营销力度}

加大营销投入力度, 利用电视、网络、报纸、广播、期 刊等多种媒介宣传本地休闲农业景点。同时举办果蔬 “采摘 游”、“农业科普培训”、“田园观光游” 等多种活动, 通过人 际交流达到宣传的目的。此外, 要加强与旅行社和其他周边 景点的合作, 进一步扩大旅游市场, 吸引更多游客来参观、休 闲、度假。

\section{6 加强生态环境保护。}

休闲农业作为现代都市农业向农村的延伸, 是现代化农 业发展的更高阶段, 它强调农业生产和人、都市、自然等诸 多要素协调起来良性发展, 而不应该以乱砍滥伐、破坏植被、 滥占耕地等造成水土流失、环境恶化为代价。“中国游客” 一度成为热搜词, 乱涂乱画、乱扔垃圾等不文明旅游现象十 分严重, 这给休闲农业良性发展带来了挑战。因此, 我们应该 制定法律法规来约束人们不文明举止, 更要提高人们生态环 境保护意识。

\section{5 结语}

重庆市休闲农业处于健康发展阶段, 已经形成良好态势, 本文从重庆市休闲农业的发展条件分析, 提出了一些发展中 存在的问题, 并给出休闲农业发展的策略, 这对于进一步促 进重庆市休闲农业的发展, 更好地满足人们的休闲旅游需求, 都具有重大意义。

\section{[参考文献]}

[1]谭志蓉.成都市休闲农业发展研究[J].中国农业资源 与区划,2017,38(02):231-236.

[2]王波。休闲农业效益评价体系构建与发展路径选择 [J].世界农业,2017,(04):61-68.

[3]马强. 产业融合视角的休闲农业发展障碍与路径选择 [J].农业经济,2017,(04):24-25. 